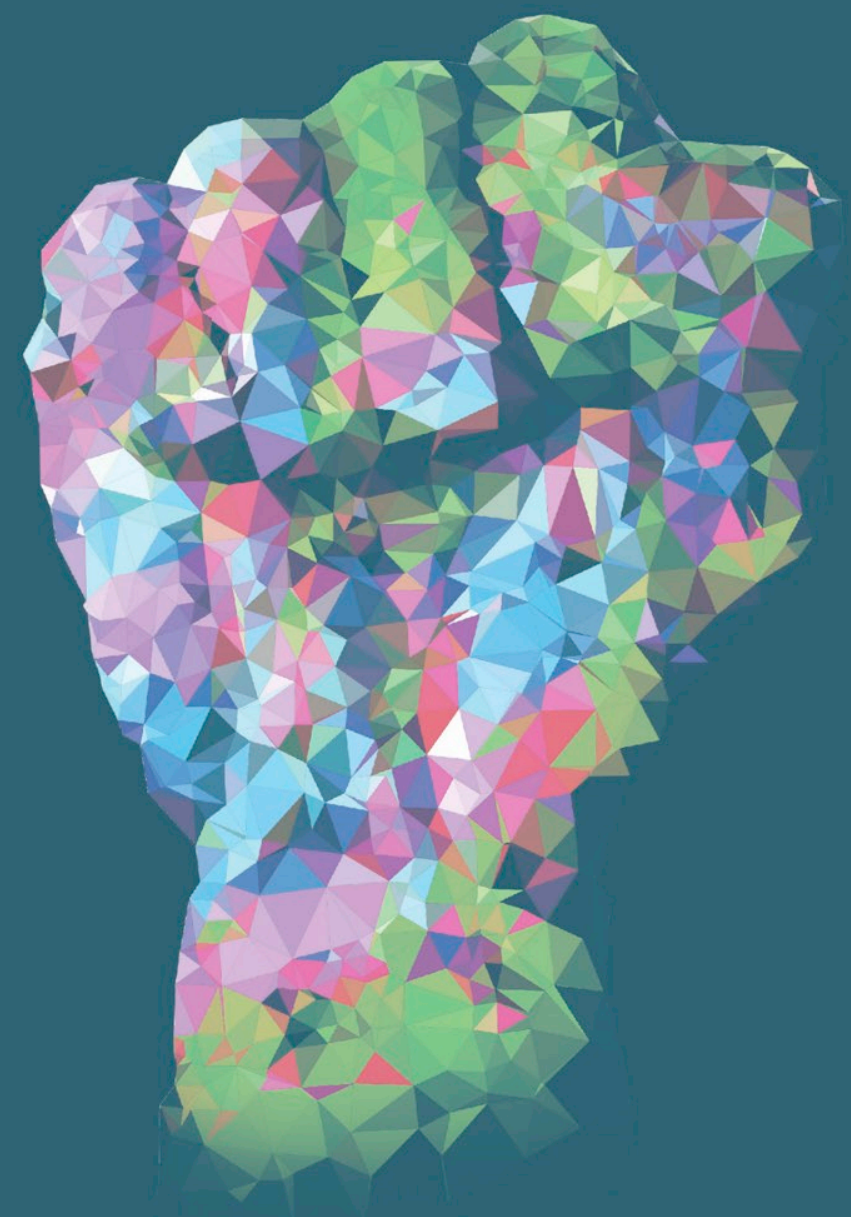

\title{
CREATIVITY
}

\section{AND RESISTANCE}

\section{口N A HOSTILE WORLD}

EDITED BY SARITA MALIK, CHURNJEET MAHN, MICHAEL PIERSE AND BEN ROGALY 


\section{Creativity and resistance in a hostile world}

\section{MANCHESTER 1824}

Manchester University Press 
Sarita Malik, Churnjeet Mahn, Michael Pierse, and Ben Rogaly - 9781526152862 Downloaded from manchesterhive.com at 04/26/2023 12:42:30PM 


\section{Creativity and resistance in a hostile world \\ Edited by Sarita Malik, Churnjeet Mahn, Michael Pierse and Ben Rogaly}

Manchester University Press 


\section{Copyright $(\odot$ Manchester University Press 2020}

While copyright in the volume as a whole is vested in Manchester University Press, copyright in individual chapters belongs to their respective authors, and no chapter may be reproduced wholly or in part without the express permission in writing of both author and publisher.

Published by Manchester University Press

Altrincham Street, Manchester M1 7JA

www.manchesteruniversitypress.co.uk

British Library Cataloguing-in-Publication Data

A catalogue record for this book is available from the British Library

ISBN 9781526152848 hardback

ISBN 9781526152855 paperback

First published 2020

The publisher has no responsibility for the persistence or accuracy of URLs for any external or third-party internet websites referred to in this book, and does not guarantee that any content on such websites is, or will remain, accurate or appropriate.

Cover Illustration: @ Shutterstock

Typeset by

New Best-set Typesetters Ltd 